\title{
White blood cell DNA adducts in a cohort of asthmatic children exposed to environmental tobacco smoke
}

\author{
Stephen E. Wilson · Glenn Talaska • Robert S. Kahn • \\ Brenda Schumann · Jane Khoury • Anthony C. Leonard • \\ Bruce P. Lanphear
}

Received: 3 November 2009/Accepted: 9 March 2010/Published online: 25 March 2010

(C) The Author(s) 2010. This article is published with open access at Springerlink.com

\begin{abstract}
Purpose Exposure to environmental tobacco smoke (ETS) leads to molecular damage in the form of DNA adducts. While lung cancer risk is higher among African Americans compared to White Americans, a few studies have tested for racial differences in DNA adducts among children exposed to ETS. The purpose of this study was to test whether African American children have higher DNA adducts levels compared to White children adjusted for ETS exposure.

Methods Data and biologic specimens were drawn from an existing cohort of 212 asthmatic children. These subjects participated in a 12-month ETS-reduction trial that employed HEPA air cleaners with active filter cartridges and sham filter cartridges. White blood cell (WBC) DNA was analyzed for DNA adducts using ${ }^{32} \mathrm{P}$-postlabeling. We assessed ETS exposure using a validated air nicotine dosimeter. We determined the independent relationship between African American race and DNA adduct levels adjusted for ETS exposure and air cleaner use.
\end{abstract}

\section{S. E. Wilson ( $\square)$}

Department of Internal Medicine, University of Cincinnati, PO Box 670535, Cincinnati, OH 45267, USA

e-mail: stephen.wilson@uc.edu

G. Talaska $\cdot$ B. Schumann · B. P. Lanphear

Department of Environmental Health,

University of Cincinnati, Cincinnati, OH, USA

\section{A. C. Leonard}

Department of Public Health Sciences,

University of Cincinnati, Cincinnati, OH, USA

\section{J. Khoury}

Division of Epidemiology and Biostatistics, Cincinnati Children's Hospital Medical Center,

Cincinnati, OH, USA
Results The mean age of the subjects was 8.4 years; 55\% were African American. There was no difference in DNA adduct levels between African American and White children (11.8 vs. 11.2 adducts per $10^{9}$ nucleotides, $p=0.86$ ), despite slightly higher levels of air nicotine exposure (3.4 vs. $2.2 \mu \mathrm{g} / \mathrm{m}^{3}, p=0.14$ ). African American children used their air cleaners less often than White children. We found that the best predictor of DNA adduct levels was the duration of air cleaner use $(r=-0.133$, $p=0.056)$. This association was independent of cartridge type.

Conclusions We did not see differences in adduct levels by race even after accounting for the level of ETS exposure. However, there was a marginal inverse association between air cleaner use and adducts. Additional research is required to understand this phenomenon.

Keywords ETS - DNA adducts - Air filters - Cotinine . Asthma $\cdot$ African American

S. E. Wilson · R. S. Kahn

Division of General and Community Pediatrics,

Cincinnati Children's Hospital Medical Center,

Cincinnati, OH, USA

B. P. Lanphear

Children's Environmental Health Center,

Cincinnati Children's Hospital Medical Center,

Cincinnati, OH, USA

B. P. Lanphear

Simon Fraser University and Child \& Family Research Institute,

Vancouver, BC, USA

B. P. Lanphear

BC Children's Hospital, Vancouver, BC, USA 


\section{Introduction}

Environmental tobacco smoke (ETS) is a widespread toxicant linked to approximately 4,000 cancer deaths per year in the US (United States, Public Health Service, Office of the Surgeon General 2006). ETS contains over 4,000 chemicals and 60 known carcinogens (IARC Working Group 2004). Polycyclic aromatic compounds (PAC) are a group of carcinogens found in ETS. When inhaled, these compounds are activated by phase I enzymes and can bind to DNA bases to form bulky products known as DNA adducts. DNA adducts can lead to mutations, which may disrupt normal cellular function and initiate carcinogenesis. Among active smokers, individuals with higher adduct levels have an increased risk of developing lung cancer (Whyatt et al. 2000; Tang et al. 2001; Veglia et al. 2003). In addition, individuals who began smoking earlier in life have a higher disease rate; this is independent of whether they continue to smoke or stop smoking (Wiencke et al. 1999). Among adults who have never smoked, DNA adduct levels are associated strongly with the development of lung cancer (Peluso et al. 2005). Children appear particularly susceptible to the genotoxic effects of ETS. Studies of mother-infant dyads have found higher DNA adduct levels in the newborns compared to the mothers despite a lower estimated exposure to ETS (Whyatt et al. 2001; Perera et al. 2004).

As with many diseases, tobacco-related disorders are not equally distributed in humans. Despite lower levels of tobacco use, African American smokers suffer higher rates of lung cancer compared with White smokers (United States Department of Heath and Human Services 1998; Haiman et al. 2006). Even among lifetime nonsmokers, African American women have a significantly higher lung cancer incidence than White women (Thun et al. 2006, 2008). These studies raise questions as to whether certain populations are more susceptible to the carcinogenic effects of tobacco or sustain exposures in excess of other groups. Weiserbs et al. reported a twofold higher level of DNA adducts among African Americans compared to White Americans and Latino Americans (Weiserbs et al. 2003). Among smokers, African Americans have higher cotinine levels (nicotine metabolite) than Whites (Caraballo et al. 1998; Benowitz et al. 1999, 2004; Ahijevych et al. 2002). There are also striking racial differences in cotinine among ETS-exposed children. In previous work, we demonstrated that African American children had higher levels of cotinine in their serum and hair than White children, despite similar levels of ETS exposure (Wilson et al. 2005, 2007). However, a few studies have tested for racial differences in DNA adducts among children adjusting carefully for ETS exposure.
The factors that result in higher levels of ETS exposure within families are complex and not completely understood. Housing size and ventilation are known to impact children's exposure to ETS, as measured by serum cotinine (Henschen et al. 1997; Wilson et al. 2005). We conducted a study to determine whether equipping the homes of asthmatic children with high-efficiency particulate arrestor (HEPA) air cleaning devices would have a positive impact on reducing exposure to ETS. We tested for differences in white blood cell (WBC) DNA adduct levels between White and African-American children, initially since the literature suggested that such a racial difference may be expected, but also because an effect was indicated in our own preliminary data with a subset of the participants.

\section{Methods}

Data for this study were drawn from the Cincinnati Asthma Prevention Study (CAP Study) (NCT00006565). The general methods used in that study have been previously described (Wilson et al. 2005, 2007; Spanier et al. 2006; Yolton et al. 2008). The CAP Study was a year-long, double blinded, placebo-controlled trial that aimed to test the efficacy of reducing ETS exposure among children with asthma using HEPA air cleaners. Each study participant received 2 HEPA air cleaners with either active or placebo cartridges. One air cleaner was placed in the main activity room while the other was placed in the child's bedroom. The objective of the current study was to test for differences in WBC PAC-DNA adducts while accounting for the level of ETS exposure. We measured adduct levels in leukocytes from whole blood samples collected at the 12-month visit of the study. In addition, we collected urine samples at the 6-month visit of the study and measured levels of 1-hydroxypyrene (1-HP). Primary variables of interest included parent-reported race and household air nicotine. In addition, we assessed ETS exposure by measuring cotinine levels in serum and hair. This study was approved by the Cincinnati Children's Hospital Medical Center Institutional Review Board (Human Subjects Protection Committee).

\section{Study population}

The study cohort consisted of a bi-racial community-based sample (55\% African American) of environmental tobacco-exposed children $(N=225)$ with asthma. We collected whole blood specimens from 212 study participants. Children were eligible for the parent study if they fulfilled the following criteria: ages 5-12 years old; physician-diagnosed asthma; exposure to $>5$ cigarettes per day in or around the home; no coexisting lung disease, heart disease or neuromuscular disease. 
Air nicotine

We assessed ETS exposure in the home by measuring air nicotine using nicotine dosimeters. The dosimeters used in this study consist of a filter treated with sodium bisulfate and contained in a $4-\mathrm{cm}$ polystyrene cassette. Nicotine passively diffuses to the dosimeter and is collected on the filter. The dosimeter was placed in a standard, unobstructed location within the main activity room of each housing unit. This room was designate by the primary caregiver as the location where family members spent most of their non-sleeping hours. Dosimeters were placed at baseline and 6 months of the study and subsequently retrieved at 6 and 12 months, respectively. For this study, we used the dosimeter measures from 6 to 12 months. The nicotine dosimeters were analyzed in Dr Katherine Hammond's laboratory at University of California at Berkeley using a standardized protocol (Marbury et al. 1993; Hammond et al. 1995; Glasgow et al. 1998; Eisner et al. 2001). Nicotine was extracted from the filter using an ethanol solution. Sodium hydroxide was added to the solution to adjust the $\mathrm{pH}$, and the solution was subsequently analyzed by gas chromatography. Nicotine levels were reported in micrograms/filter. The passive monitors have a limit of detection of $0.01 \mu \mathrm{g} / \mathrm{filter}$ $\left(0.01 \mu \mathrm{g} / \mathrm{m}^{3}\right)$ (Hammond et al. 1995; Eisner et al. 2001).

\section{Race}

For this study, we assessed race by surveying the primary caregiver. The primary caregiver of each subject was asked to select their child's race (African American or Black, White, Asian or Asian American, Asian Indian, Native American, Native Hawaiian/Pacific Islander, Middle Eastern) and ethnicity (Hispanic or Non-Hispanic). Because the cohort was primarily African American and White (95\%), we excluded other racial and ethnic groups for the purpose of this analysis. Parents were instructed to select as many of the categories as they deemed appropriate. Because there were a few subjects in other racial and ethnic categories, only those children reported to be African American or White were included in our analysis. Children who were described as African American and White were categorized as mixedrace subjects $(n=8)$. We performed a sensitivity analysis with mixed-race subjects included with African American subjects and then with White subjects to determine whether there were any differences. Since the mixed-race individuals had no impact on the final results, we included them with African Americans as we have done in our previous studies.
Cotinine

In addition to air nicotine, we assessed ETS exposure by measuring cotinine levels in children's serum and hair. We collected serum and hair samples at baseline, 6 and 12 months of the study. Serum cotinine, a short-term measure of tobacco smoke exposure, has a half-life of 15$25 \mathrm{~h}$ and reflects tobacco exposure in the prior 3-4 days. Serum samples were analyzed at the CDC's National Center for Environmental Health using a well-validated protocol (Bernert et al. 1997, 2000; United States Department of Heath and Human Services 1998; Muscat et al. 2002; Ahijevych and Garrett 2004). Briefly, serum samples were analyzed for cotinine using high performance liquid chromatography (HPLC) linked to atmospheric-pressure chemical ionization tandem mass spectrometry. Trichloroacetic acid was added to each specimen followed by potassium hydroxide to neutralize this mixture. Cotinine was extracted using methylene chloride and subsequently injected into the HPLC column. Cotinine was monitored in the eluant by mass spectrometry (limit of detection $=0.05 \mathrm{ng} / \mathrm{ml}$ ). Hair cotinine levels provided estimates of ETS exposure in the previous 3 months. Hair samples from the occipital scalp were transported to the Division of Clinical Pharmacology at the University of Toronto and analyzed using a well-validated procedure (Knight et al. 1996; Klein and Koren 1999). These hair samples were washed and dried with a mild detergent. Cotinine was extracted from the hair using sodium hydroxide. This solution was neutralized using hydrochloric acid. Cotinine concentrations were determined using radioimmunoassay as previously described in the literature (Eliopoulos et al. 1994; Klein and Koren 1999). Hair cotinine values were reported in nanograms (ng) of cotinine per milligram $(\mathrm{mg})$ of hair with a limit of detection of $0.005 \mathrm{ng} / \mathrm{mg}$.

\section{DNA adducts}

We analyzed PAC-DNA adducts in white blood cells using a ${ }^{32} \mathrm{P}$-postlabeling technique. ${ }^{32} \mathrm{P}$-postlabeling is a very sensitive method that does not require that the identity of the agent be known a priori. With this technique, we have been able to detect carcinogen-DNA adducts at levels of $0.01-0.1$ adducts $/ 10^{8}$ nucleotides using as little as $100 \mathrm{pmol}$ of DNA. The samples are ${ }^{32} \mathrm{P}$-postlabeled with an excess of $\left[{ }^{32} \mathrm{P}\right] \mathrm{ATP}$ and allow calculation of the relative adduct level (RAL).

$\mathrm{RAL}=\left(\frac{c p m_{\text {adducts }}}{\left.1.25 \times 10^{6} / \mathrm{pmol} \mathrm{ATP} \times(3240 \mathrm{pmol} \mathrm{dNP} / \mu g \mathrm{DNA}) \times \mu g \mathrm{DNA}\right)}\right) \times 10^{9}$ 
where $\mu \mathrm{g}$ DNA is the amount of DNA in the specific sample.

Frozen samples were stored at $-80^{\circ} \mathrm{C}$ until analysis. Blood samples were rapidly thawed in warm water and centrifuged to collect the WBC. The pellet was resuspended in $1 \mathrm{ml}$ of $1 \%$ SDS, $10 \mathrm{mM}$ EDTA and frozen $\left(-80^{\circ} \mathrm{C}\right)$ until the DNA was isolated. DNA was isolated using the common enzyme-solvent method where ribonucleic acids and proteins are degraded and the latter extracted into an organic phase while the former remains in solution when DNA is precipitated in ethanol. DNA was resolubilized in a small volume (10-20 $\mu \mathrm{l})$ of 0.01 Sorenson's sodium citrate. We digested DNA to $3^{\prime}$-phosphodeoxynucleosides using $2.5 \mu \mathrm{g}$ calf spleen phosphodiesterase and $0.25 \mathrm{U}$ micrococcal endonuclease. We added Nuclease P1 to the mixture to enhance kinase selection of adducted monophosphates. Samples were labeled with $250 \mu \mathrm{Ci}\left[{ }^{32} \mathrm{P}\right]$ ATP per sample. Subsequently, we spotted 5-20 $\mu$ of the ${ }^{32} \mathrm{P}$-labeled sample onto polyethyleneimine-modified (PEI) cellulose sheets and placed them in the liquid chromatography chamber. Adduct levels were measured using autoradiography on the chromatograms (Talaska et al. 1990, 1991a, b; Reichert and French 1994). All samples were analyzed in duplicate at least. A positive control (DNA from animals exposed to benzo(a)pyrene) was analyzed with every sample run.

\section{1-Hydroxypyrene}

We collected urine specimens at the 6-month study visit and assayed them for 1-HP using a standardized method (Jongeneelen et al. 1988). Urinary 1-HP was analyzed by high performance liquid chromatography (HPLC) (Waters 680 Automated Gradient Controller; and reverse phase column $10 \mathrm{~cm} \times 4 \mathrm{~mm}$ I.D.) with fluorescence detection (Waters 730 Data Module), after enzymatic hydrolysis. The mobile phase used was methanol-water at a flow rate of $1 \mathrm{ml} / \mathrm{min}$. The excitation wavelength of the fluorescence detector for 1-HP was set to $242 \mathrm{~nm}$ and the emission wavelength to $388 \mathrm{~nm}$. Creatinine was measured in urine samples using a creatinine kit (Stanbio Direct Creatinine LiquiColor Procedure No. 0420) and a spectrophotometer (Beckman Coulter DU800). All values are reported in ng/g of creatinine.

\section{Variables of interest}

We collected extensive measures of household characteristics and parental smoking habits during each study visit. First, we assessed the size of the home. We calculated the dimensions of each room using an electronic tape measure. Then, we totaled the volume of the rooms to obtain an overall home volume. In addition, we surveyed the primary caregiver about the number of cigarettes smoked around the child per day. We asked the primary caregiver to estimate the number of hours per day that the child was in the same room as a smoker. Each HEPA unit was equipped with a counter to document hours of air cleaner use. We documented total hours of use for the entire study period. Lastly, we collected information on asthma-related healthcare utilization and asthma medication use in the previous 3 months. Realizing that time of year can have an impact on these factors, we also documented the season of the year (winter, spring, fall summer) when the home visit occurred.

\section{Statistical analysis}

We tested for differences in predictors and outcomes using parametric and non-parametric tests as appropriate. We estimated the means and variances for continuous variables and the frequencies and proportions for categorical variables. Since the distributions of air nicotine, serum cotinine, hair cotinine, urine 1-HP and DNA adducts were highly skewed, we log-transformed these data prior to any analysis. We tested for racial differences in PAC-DNA adducts, air nicotine, urine 1-HP, serum cotinine and hair cotinine using $t$-tests. Differences in health care utilization were tested using the wilcoxon rank sum test. In our sample, there were 117 children identified as African American and 95 identified as White. Assuming a twotailed alpha $=0.05$ and power of 0.8 , we estimated the ability to detect a difference in adduct levels of 0.34 adducts per $10^{8}$ nucleotides. The ${ }^{32} \mathrm{P}$-postlabeling technique has a limit of detection of $0.01-0.1$ adducts per $10^{8}$ nucleotides (Reichert and French 1994; Talaska et al. 1995, 2002). Thus, the effect size is well above our limit of detection.

Using the Pearson correlations, we tested for significant associations between DNA adducts and markers of ETS exposure (air nicotine, serum cotinine and hair cotinine). Also, we tested for associations between air cleaner use and asthma severity - as measured by health care utilization and asthma medication use. Since air nicotine levels are not impacted by metabolism, we use it as our primary measure of ETS exposure. Since the urine samples were collected at 6 months and 1-HP levels represent recent exposure to PACs, we did not test for associations between 1-HP and other markers of ETS exposure, which were collected at the 12-month visit. To determine the independent relationship between African American race and DNA adducts, we constructed a multivariable linear regression model with DNA adducts as the outcome. Since these data were drawn from a randomized trial, we tested for differences in DNA adduct levels by group assignment (active vs. placebo). All analyses were conducted in SAS 9.1 (Cary, NC). 


\section{Results}

We measured DNA adduct levels in whole blood samples of 212 participants in the Cincinnati Asthma Prevention Study. The mean age of the children in the sample was 8.4 years. Of the participants, 55\% were African American and $37 \%$ were women. There were no significant racial differences in age, gender or health care utilization. We examined factors that might impact DNA adduct levels. We found that African American children lived in smaller homes with marginally higher air nicotine levels than White children (3.4 vs. $2.2 \mu \mathrm{g} / \mathrm{m}^{3}, p=0.145$ ) (Table 1). On the other hand, African American children were exposed to fewer hours of active smoking per day than White children, but this difference was also not statistically significant. On average, households with White children used the air cleaners more often than those with African American children (6795 vs. 5530 h, $p<0.001$ ). However, we did not find an association between air cleaner use and health care utilization or asthma treatment (data not shown). While air cleaner use was marginally associated with DNA adduct levels ( $p=-0.133, p=0.056$ ), there were no differences in DNA adducts between children with active and control filter cartridges (11.6 vs. 11.5 adducts per $10^{9}$ nucleotides, $p=0.97$ ).

Consistent with previous studies, we noted that African American children had higher levels of both serum and hair cotinine compared to White children. Despite differences in cotinine, we found no significant racial differences in DNA adduct levels. African American and White children had similar levels of DNA (11.8 vs. 11.2 adducts per $10^{9}$ nucleotides, $p=0.86$ ). Also, we found no significant racial differences in urine levels of 1-HP. We tested for associations between DNA adducts and markers of ETS exposure. First, we tested for a relationship between air nicotine and biologic measures of cotinine and found significant associations (Table 2). However, we found no statistically significant associations between DNA adducts and either hair or serum cotinine. In addition, there was no association between DNA adducts and integrated air nicotine levels.

Subsequently, we used multivariable modeling to test for independent associations between DNA adducts and other variables of interest (Table 3 ). We included air nicotine as the objective marker of ETS exposure, since it is not impacted by metabolic differences. Still, there were no differences in DNA adducts by race or sex after accounting of ETS exposure, home volume or age. While air cleaner use was marginally significant in the bivariate model, it was not significantly associated with DNA adduct levels in the multivariable model.

\section{Discussion}

We report that overall air cleaner use was marginally associated with DNA adduct levels regardless of the child's race or sex. This finding is interesting particularly since it was independent of whether or not the air cleaner contained an active HEPA unit. There are at least two potential explanations for these data. It could be that the majority of carcinogens in ETS that can be detected in blood lymphocytes are not bound to particles but remain in the vapor phase. Vapor phase carcinogens would not be filtered by the HEPA filters in the units. This possibility is consistent with our finding that the air levels of nicotine, a vapor

Table 1 Demographic characteristics and biomarker levels by race

\begin{tabular}{|c|c|c|c|}
\hline & African American $(N=117)$ & White American $(N=95)$ & $p$-Value \\
\hline Age (years) (SD) & $8.8(1.8)$ & $8.4(1.8)$ & 0.127 \\
\hline Women $(\%)$ & 40.2 & 35.8 & 0.51 \\
\hline Cigarettes smoked around the home per day (cigs/day) (SD) & $10.4(9.1)$ & $17.0(12.2)$ & $<0.001$ \\
\hline Home volume $\left(\mathrm{m}^{3}\right)(\mathrm{SD})$ & $209.5(78.2)$ & $240.3(104.6)$ & 0.018 \\
\hline Health care utilization $(\text { mean } \pm \mathrm{SD})^{*,+}$ & $0.45(0.74)$ & $0.61(1.10)$ & 0.57 \\
\hline Reported inhaled steroid use (\%) & 22.5 & 27.1 & 0.44 \\
\hline Smoking in the same room (h/day)** & $0.75(0.42-1.1)$ & $1.2(0.7-1.6)$ & 0.148 \\
\hline Air cleaner use (h) (SD) & $5,530(2,800)$ & $6,794(2,968)$ & $<0.001$ \\
\hline Air nicotine $\left(\mu \mathrm{g} / \mathrm{m}^{3}\right)(95 \% \mathrm{CI})$ & $3.4(2.4-4.7)$ & $2.2(1.4-3.6)$ & 0.145 \\
\hline Serum cotinine $(\mathrm{ng} / \mathrm{ml})(95 \% \mathrm{CI})$ & $1.4(1.1-1.9)$ & $0.83(0.6-1.1)$ & 0.011 \\
\hline Hair cotinine $(\mathrm{ng} / \mathrm{mg})(95 \% \mathrm{CI})$ & $0.28(0.24-0.34)$ & $0.07(0.06-0.1)$ & $<0.001$ \\
\hline Urine 1-HP (ng/g creatinine) $(95 \% \mathrm{CI})$ & $27.7(20.3-37.8)$ & $32.5(24.3-43.5)$ & 0.457 \\
\hline DNA adducts (per $10^{9}$ nucleotides) & $11.9(7.4-19.0)$ & $11.2(6.8-18.4)$ & 0.863 \\
\hline
\end{tabular}

Data presented as \%, * mean (SD) and ** geometric mean $(95 \% \mathrm{CI})$

+ Health care utilization defined as unscheduled clinic visit, emergency department visit or hospitalization 
Table 2 Correlation coefficients between DNA adduct levels and other variables of interest

\begin{tabular}{|c|c|c|c|c|c|c|}
\hline & $\begin{array}{l}\text { DNA } \\
\text { adducts }\end{array}$ & $\begin{array}{l}\text { Air } \\
\text { cleaner } \\
\text { use }\end{array}$ & $\begin{array}{l}\text { Cigarettes } \\
\text { smoked around } \\
\text { the home }\end{array}$ & $\begin{array}{l}\text { Air } \\
\text { nicotine }\end{array}$ & $\begin{array}{l}\text { Serum } \\
\text { cotinine }\end{array}$ & $\begin{array}{l}\text { Hair } \\
\text { cotinine }\end{array}$ \\
\hline \multirow[t]{3}{*}{ DNA adducts } & \multirow[t]{3}{*}{1.0} & -0.133 & 0.016 & -0.044 & 0.055 & 0.028 \\
\hline & & 0.0563 & 0.8188 & 0.533 & 0.4259 & 0.6989 \\
\hline & & 208 & 205 & 205 & 212 & 197 \\
\hline \multirow[t]{3}{*}{ Air cleaner use } & & 1.0 & 0.044 & -0.008 & -0.152 & -0.217 \\
\hline & & & 0.5343 & 0.9067 & 0.0282 & 0.0025 \\
\hline & & & 201 & 202 & 208 & 193 \\
\hline \multirow[t]{3}{*}{ Cigarettes smoked around the home } & & & 1.0 & 0.326 & 0.323 & -0.030 \\
\hline & & & & $<0.0001$ & $<0.0001$ & 0.6784 \\
\hline & & & & 198 & 205 & 190 \\
\hline \multirow[t]{3}{*}{ Air nicotine } & & & & 1.0 & 0.645 & 0.275 \\
\hline & & & & & $<0.0001$ & 0.0001 \\
\hline & & & & & 205 & 190 \\
\hline \multirow[t]{3}{*}{ Serum cotinine } & & & & & 1.0 & 0.478 \\
\hline & & & & & & $<0.0001$ \\
\hline & & & & & & 197 \\
\hline Hair cotinine & & & & & & 1.0 \\
\hline
\end{tabular}

Table 3 Multivariable regression model for DNA adducts

\begin{tabular}{lcl}
\hline Variable of interest & B coefficient & $p$-Value \\
\hline Air nicotine & -0.029 & 0.76 \\
African American race & 0.277 & 0.458 \\
Home volume (per m ${ }^{3}$ ) & -0.0007 & 0.727 \\
Smoking in room with child (per hour) & -0.038 & 0.679 \\
Air cleaner use & -0.0001 & 0.1034 \\
Age & 0.085 & 0.408 \\
Women & -0.405 & 0.268 \\
\hline
\end{tabular}

phase material, did not vary by air cleaner usage or type. Prior studies have demonstrated an association between housing size and ventilation, and other markers of tobacco smoke exposure (Henschen et al. 1997; Wilson et al. 2005). However, there is another plausible explanation. It is possible that since the air cleaners had to be turned off and on by the parent that increased time of air cleaner usage may also be surrogate indicator of unmeasured behavior changes within the family that resulted in lower exposure to ETS among the children.

While we confirmed racial differences in both hair and serum cotinine, we did not find significant racial differences in DNA adducts. The absence of a difference in DNA adducts was surprising, given that African American children were exposed to marginally higher levels of ETS compared to White children and used their air cleaners less. Our results differ from other studies that have reported racial differences in DNA adducts. In Weiserbs' cohort study, the authors reported that African American smokers had WBC DNA adduct levels that exceeded both White and Hispanic smokers by twofold, even after accounting for current smoking levels and lifetime tobacco use (Weiserbs et al. 2003). Wang et al. also reported striking racial differences in DNA adducts in a cohort of nonsmoking women, but in the opposite direction (Wang et al. 2008). The authors recruited subjects from New York City (primarily African American and Dominican) and Krakow Poland (European) and tested for racial differences in DNA adducts. DNA adducts in European women exceeded those of African American women by twofold. However, exposure to air pollution was substantially higher among European women compared to African American women. In contrast, another study reported no racial difference in DNA adducts among smokers. In a case-control study of African American and Mexican American lung cancer patients, Vulimiri et al. found striking racial differences in DNA adducts among cancer patients (Vulimiri et al. 2000). Mexican American subjects $(n=37)$ had aromatic DNA adduct levels that were $38 \%$ higher than African American subjects $(n=6)$, but there were no significant racial differences in DNA adduct levels among the control subjects.

The absence of a racial differences in DNA adducts in this cohort is surprising. It has been documented in previous studies that African American smokers suffer higher rates of lung cancer when compared with White smokers, despite lower reported levels of tobacco use (United States Department of Heath and Human Services 1998; United States, Public Health Service, Office of the Surgeon General 2006). Certainly, Haiman et al. demonstrated higher lung cancer rates among African Americans compared with all other racial and ethnic groups (Haiman et al. 2006). This phenomenon has also been observed among lifetime 
non-smokers. Data from the Cancer Prevention Study II Cohort identified an increased risk of lung cancer mortality among African American women when compared with White women (HR $=1.43, \mathrm{CI}=1.11-1.85)$ (Thun et al. 2006). Given that DNA adducts are associated with the development of lung tumors, it is plausible that African Americans would have higher adduct levels (Tang et al. 2001; Peluso et al. 2005). However, our data do not support this hypothesis. There are some possible explanations for our findings. First, we measured adducts in a surrogate tissue (WBCs) rather than the target tissue (lung). Thus, the WBC DNA adducts may not represent the aggregate amount of tobacco-induced damage occurring in the lungs. Moreover, WBCs may represent a surrogate for other exposures in adults that are not experienced by children, to the same extent. Thus, these exposures could be associated with a smoking lifestyle. In addition, our cohort consisted solely of non-smoking children; studies of racial differences in lung cancer have focused primarily on smoking adults, and may be racial differences in DNA adducts occur only among active smokers. Lastly, the absence of racial differences in 1-Hydroxypyrene could indicate that there may have been unmeasured sources of PACs in our study.

Our results are subject to some limitations. First, our study was cross-sectional in design. At best, we could only identify an association between adducts and tobacco smoke exposure. Second, air nicotine levels were only measured in the main activity room of the home. Thus, there may have been unmeasured exposures in other parts of the home or outside of the home that contributed to adduct formation. Thus, parents may have smoked around their child in other parts of the home that would not have been captured by the nicotine dosimeter. In addition, we were unable to determine the impact of the air cleaners on PACs-compounds likely leading to adduct formation-as airborne levels of these compounds were not directly measured. Unfortunately, urine 1-HP levels cannot differentiate inhaled versus ingested exposure to PACs, and 1-HP levels reflect only recent exposure to PAC materials. While we did measure serum and hair cotinine levels that would capture ETS exposures outside of the home, it is well known that these biomarkers differ significantly by race. Still, we did not find any association of WBC DNA adducts with serum cotinine or hair cotinine-which operate as aggregate biomarkers of exposure. Third, we only measured PAC-DNA adducts, which may represent only a fraction of DNA damage induced by tobacco smoke. Aromatic amines are another family of compounds found in ETS that can form adducts with DNA (Talaska et al. 1991a, b; Hecht 2001, 2004). Fourth, there may have been sources of PACs other than ETS-such as exhaust from automobiles or dietary intake-that were not measured by the air nicotine dosimeters. Exposure to automobile exhaust and consumption of charbroiled foods have both been linked to higher PAC-DNA adduct levels (Rothman et al. 1993; Perera et al. 2005). Lastly, all of the subjects in this study had asthma. It is unknown whether these results are generalizable to children without asthma.

Despite the results, our study did employ some unique strategies. We assembled a bi-racial cohort of tobaccoexposed children with asthma, which allowed us to explore factors that might contribute to DNA damage. While other studies have used ELISA tests, we used ${ }^{32} \mathrm{P}$-postlabeling with nuclease P1 enhancement to measure DNA adducts in our study sample. This process allowed for the detection of very low levels of PAC-DNA adducts $\left(0.01\right.$ adducts per $10^{9}$ nucleotides) without prior knowledge of the identity of the compounds (Reddy et al. 1981; Reddy and Randerath 1986). We assessed ETS exposure in the home using a validated air nicotine dosimeter. The dosimeters provided an objective measurement of the child's in-home exposure to ETS for 6 months prior to the measurement of the DNA adducts. To our knowledge, this is the first study to attempt to correlate air nicotine levels with DNA adducts in a cohort of ETS-exposed children with asthma. Also, we demonstrated a non-significant trend toward an inverse relationship between air cleaner use and DNA adduct levels. Even though there were no differences in adduct levels between subjects with active and control filters, it is notable that increased use of the air cleaner trended toward lower DNA adduct levels. Potentially, improved room ventilation may reduce DNA adduct levels. Further studies are required to confirm and extend these findings.

Acknowledgments We would like to thank Dr. Nancy Hopf for her assistance with the 1-hydroxypyrene analyses. Funding for this study was provided by NCI-1K01CA123355-01A1 (SEW, GT, ACL, BS), The American Academy of Pediatrics Julius P. Richmond Center and Flight Attendant Medical Research Institute, and NHLBI-HL65731 (BPL).

Conflict of interest statement The authors of this manuscript declare no competing interest.

Open Access This article is distributed under the terms of the Creative Commons Attribution Noncommercial License which permits any noncommercial use, distribution, and reproduction in any medium, provided the original author(s) and source are credited.

\section{References}

Ahijevych K, Garrett BE (2004) Menthol pharmacology and its potential impact on cigarette smoking behavior. Nicotine Tob Res 6(Suppl 1):S17-S28

Ahijevych K, Tyndale RF et al (2002) Factors influencing cotinine half-life during smoking abstinence in African American and Caucasian women. Nicotine Tob Res 4:423-431 
Benowitz NL, Perez-Stable EJ et al (1999) Ethnic differences in $\mathrm{N}$-glucuronidation of nicotine and cotinine. J Pharmacol Exp Ther 291:1196-1203

Benowitz NL, Herrera B et al (2004) Mentholated cigarette smoking inhibits nicotine metabolism. J Pharmacol Exp Ther 310:1208-1215

Bernert JT Jr, Turner WE et al (1997) Development and validation of sensitive method for determination of serum cotinine in smokers and nonsmokers by liquid chromatography/atmospheric pressure ionization tandem mass spectrometry. Clin Chem 43:2281-2291

Bernert JT Jr, McGuffey JE et al (2000) Comparison of serum and salivary cotinine measurements by a sensitive high-performance liquid chromatography-tandem mass spectrometry method as an indicator of exposure to tobacco smoke among smokers and nonsmokers. J Anal Toxicol 24:333-339

Caraballo RS, Giovino GA et al (1998) Racial and ethnic differences in serum cotinine levels of cigarette smokers: Third National Health and Nutrition Examination Survey, 1988-1991. J Am Med Assoc 280:135-139

Eisner MD, Katz PP et al (2001) Measurement of environmental tobacco smoke exposure among adults with asthma. Environ Health Perspect 109:809-814

Eliopoulos C, Klein J et al (1994) Hair concentrations of nicotine and cotinine in women and their newborn infants. J Am Med Assoc 271:621-623

Glasgow RE, Foster LS et al (1998) Developing a brief measure of smoking in the home: description and preliminary evaluation. Addict Behav 23:567-571

Haiman CA, Stram DO et al (2006) Ethnic and racial differences in the smoking-related risk of lung cancer. $\mathrm{N}$ Engl J Med 354:333-342

Hammond SK, Sorensen G et al (1995) Occupational exposure to environmental tobacco smoke. J Am Med Assoc 274:956-960

Hecht SS (2001) Carcinogen biomarkers for lung or oral cancer chemoprevention trials. Int Agency Res Cancer Sci Publ 154:245-255

Hecht SS (2004) Carcinogen derived biomarkers: applications in studies of human exposure to secondhand tobacco smoke. Tob Control 13(Suppl 1):i48-i56

Henschen M, Frischer T et al (1997) The internal dose of passive smoking at home depends on the size of the dwelling. Environ Res 72:65-71

IARC Working Group (2004) Tobacco smoke and involuntary smoking. IARC monographs on the evaluation of carcinogenic risks to humans. W. H. Organization. Lyon, France, IARC

Jongeneelen FJ, vd Akker W et al (1988) 1-Hydroxypyrene as an indicator of the mutagenicity of coal tar after activation with human liver preparations. Mutat Res 204:195-201

Klein J, Koren G (1999) Hair analysis-a biological marker for passive smoking in pregnancy and childhood. Hum Exp Toxicol 18:279-282

Knight JM, Eliopoulos C et al (1996) Passive smoking in children. Racial differences in systemic exposure to cotinine by hair and urine analysis. Chest 109:446-450

Marbury MC, Hammond SK et al (1993) Measuring exposure to environmental tobacco smoke in studies of acute health effects. Am J Epidemiol 137:1089-1097

Muscat JE, Richie JP Jr et al (2002) Mentholated cigarettes and smoking habits in whites and blacks. Tob Control 11:368-371

Peluso M, Munnia A et al (2005) DNA adducts and lung cancer risk: a prospective study. Cancer Res 65:8042-8048

Perera FP, Tang D et al (2004) Biomarkers in maternal and newborn blood indicate heightened fetal susceptibility to procarcinogenic DNA damage. Environ Health Perspect 112:1133-1136

Perera F, Tang D et al (2005) DNA damage from polycyclic aromatic hydrocarbons measured by benzo[a]pyrene-DNA adducts in mothers and newborns from Northern Manhattan, the World Trade Center Area, Poland, and China. Cancer Epidemiol Biomarkers Prev 14:709-714

Reddy MV, Randerath K (1986) Nuclease P1-mediated enhancement of sensitivity of 32P-postlabeling test for structurally diverse DNA adducts. Carcinogenesis 7:1543-1551

Reddy MV, Gupta RC et al (1981) 32P-base analysis of DNA. Anal Biochem 117:271-279

Reichert W, French B (1994) 32P-postlabeling protocals for assaying levels of hydrophobic DNA adducts in fish. NOAA technical memorandum. N. M. F. Service. Seattle, Washington, National Oceanic and Atmospheric Administration

Rothman N, Poirier MC et al (1993) Association of PAH-DNA adducts in peripheral white blood cells with dietary exposure to polyaromatic hydrocarbons. Environ Health Perspect 99:265-267

Spanier AJ, Hornung R et al (2006) Environmental exposures and exhaled nitric oxide in children with asthma. J Pediatr 149:220-226

Talaska G, Dooley KL et al (1990) Detection and characterization of carcinogen-DNA adducts in exfoliated urothelial cells from 4-aminobiphenyl-treated dogs by 32P-postlabelling and subsequent thin-layer and high-pressure liquid chromatography. Carcinogenesis 11:639-646

Talaska G, al-Juburi AZ et al (1991a) Smoking related carcinogenDNA adducts in biopsy samples of human urinary bladder: identification of $\mathrm{N}$-(deoxyguanosin-8-yl)-4-aminobiphenyl as a major adduct. Proc Natl Acad Sci USA 88:5350-5354

Talaska G, Schamer M et al (1991b) Detection of carcinogen-DNA adducts in exfoliated urothelial cells of cigarette smokers: association with smoking, hemoglobin adducts, and urinary mutagenicity. Cancer Epidemiol Biomarkers Prev 1:61-66

Talaska G, Roh J et al (1995) 32P-postlabelling analysis of dibenz[a, j]acridine-DNA adducts in mice: identification of proximate metabolites. Chem Biol Interact 95:161-174

Talaska G, Maier A et al (2002) Carcinogen biomonitoring in human exposures and laboratory research: validation and application to human occupational exposures. Toxicol Lett 134:39-49

Tang D, Phillips DH et al (2001) Association between carcinogenDNA adducts in white blood cells and lung cancer risk in the physicians health study. Cancer Res 61:6708-6712

Thun MJ, Henley SJ et al (2006) Lung cancer death rates in lifelong nonsmokers. J Natl Cancer Inst 98:691-699

Thun MJ, Hannan LM et al (2008) Lung cancer occurrence in neversmokers: an analysis of 13 cohorts and 22 cancer registry studies. Public Libr Sci Med 5:e185

United States Department of Heath and Human Services (1998) Tobacco use among U.S. racial/ethnic minority groups African Americans, American Indians and Alaska natives, Asian Americans and Pacific Islanders, Hispanics: a report of the Surgeon General. [Atlanta, Ga.], CDC

United States, Public Health Service, Office of the Surgeon General (2006) The health consequences of involuntary exposure to tobacco smoke: a report of the Surgeon General. Rockville, MD, U.S. Dept. of Health and Human Services, Public Health Service, Office of the Surgeon General

Veglia F, Matullo G et al (2003) Bulky DNA adducts and risk of cancer: a meta-analysis. Cancer Epidemiol Biomarkers Prev 12:157-160

Vulimiri SV, Wu X et al (2000) Analysis of aromatic DNA adducts and 7,8-dihydro-8-oxo-2' deoxyguanosine in lymphocyte DNA from a case-control study of lung cancer involving minority populations. Mol Carcinog 27:330

Wang S, Chanock S et al (2008) Assessment of interactions between PAH exposure and genetic polymorphisms on PAH-DNA adducts in African American, Dominican, and Caucasian mothers and newborns. Cancer Epidemiol Biomarkers Prev 17:405-413 
Weiserbs KF, Jacobson JS et al (2003) A cross-sectional study of polycyclic aromatic hydrocarbon-DNA adducts and polymorphism of glutathione S-transferases among heavy smokers by race/ethnicity. Biomarkers 8:142-155

Whyatt RM, Perera FP et al (2000) Association between polycyclic aromatic hydrocarbon-DNA adduct levels in maternal and newborn white blood cells and glutathione S-transferase P1 and CYP1A1 polymorphisms. Cancer Epidemiol Biomarkers Prev 9:207-212

Whyatt RM, Jedrychowski W et al (2001) Biomarkers of polycyclic aromatic hydrocarbon-DNA damage and cigarette smoke exposures in paired maternal and newborn blood samples as a measure of differential susceptibility. Cancer Epidemiol Biomarkers Prev 10:581-588
Wiencke JK, Thurston SW et al (1999) Early age at smoking initiation and tobacco carcinogen DNA damage in the lung. J Natl Cancer Inst 91:614-619

Wilson SE, Kahn RS et al (2005) Racial differences in exposure to environmental tobacco smoke among children. Environ Health Perspect 113:362-367

Wilson SE, Kahn RS et al (2007) The role of air nicotine in explaining racial differences in cotinine among tobacco-exposed children. Chest 131:856-862

Yolton K, Khoury J et al (2008) Environmental tobacco smoke exposure and child behaviors. J Dev Behav Pediatr 29:450-457 